\title{
KUALITAS PAPAN ISOLASI DARI CAMPURAN KAYU MANGIUM (Acacia mangium Willd) DAN ARANG
}

\author{
(Quqlity of Insulation Board from the Mixture of Mangium Wood \\ and Fiber Charcoal)
}

\author{
Oleh/By : \\ Saptadi Darmawan ${ }^{1)}$ \\ ${ }^{1)}$ Peneliti pada Balai Penelitian Kehutanan Mataram \\ Diterima 11 Mei 2009, disetujui 25 Agustus 2009
}

\begin{abstract}
Utilization of small-diameter wood logs $(<10 \mathrm{~cm})$ from plantation forest is still not yet optimal despite their significant potential. This wood can be used as raw material to produce the so-called insulation board. In relevant, this research was conducted on possible use of small-diameter mangium (Acacia mangium) wood, after being pulped, for the manufacture of insulation board. In order to enhance the uses of that board not only for insulation but also for other purpose (e.g. gas / vapor adsorption), before the forming of insulation board mat, the mangium pulp was mixed with fiber charcoal (resulting from the carbonization of mangium and rubber wood fiber) in four various proportion, i.e consecutively 100:0, 90:10, 80:20 and 70:30 (w/ w). The mangium pulp was produced using open-soda semi-chemical process. The qualities of all resulting insulation board could meet the Japan standard except thickness swelling. Based on the total score assessment, physical-mechanical properties, adsorption capasity, it revealed that the insulation board from the mixture of mangium pulp and charcoal at 90:10 and 100:0 (control) proportions perform optimally. This indicated that smalldiameter mangium wood can be utilized for the manufacture of insulation board with satisfactory qualities/performance.
\end{abstract}

Keyword: Small-diameter wood logs, plantation forest, mangium woodpulp, fiber charcoal, insulation board, gas / vapor adsorption

\begin{abstract}
ABSTRAK
Potensi kayu berdiameter kecil $(<10 \mathrm{~cm})$ dari hutan tanaman cukup besar namun belum dimanfaatkan secara optimal. Sesungguhnya kayu tersebut dapat digunakan sebagai bahan baku pembuatan papan isolasi. Pada penelitian ini menggunakan kayu mangium (Acacia mangium) berdiameter kecil untuk dijadikan pulp, kemudian digunakan dalam pembuatan papan isolasi. Selanjutnya guna meningkatkan fungsi dari papan tersebut, tidak hanya sebagai insulation juga sebagai penyerap gas/uap, maka sebelum dibentuk lembaran papan, pulp mangium dicampur terlebih dahulu dengan arang serat (hasil pengarangan serat kayu mangium dan karet) pada beberapa komposisi yaitu 100:0, 90:10, 80:20 and 70:30 (w/w). Pulp mangium dibuat dengan proses soda panas terbuka. Kualitas papan isolasi yang dibuat telah memenuhi standar Jepang kecuali untuk pengembangan tebalnya. Berdasarkan nilai scoring, kerapatan, dan sifat fisik-mekanik papan isolasi serta dibandingkan dengan standar Jepang maka papan isolasi yang optimal diperoleh pada kontrol dan komposisi pulp dan arang 90:10. Sifat-sifat tersebut mengindikasikan bahwa kayu mangium berdiamater kecil dapat dibuat papan isolasi dengan kualitas yang baik.
\end{abstract}


Kata kunci: Kayu berdiameter kecil, hutan tanaman, pulp kayu mangium, arang serat, papan isolasi, daya serap terhadap gas/uap

\section{PENDAHULUAN}

Penggunaan panel kayu sebagai bahan komplement produk kayu utuh terus berkembang. Produk panel kayu memiliki beberapa keunggulan diantaranya dapat meningkatkan efisiensi bahan baku, mudah dalam penggunaannya, dan ketersediaan bahan baku dapat lebih terjamin. Efisiensi penggunaan bahan baku tersebut dapat dilakukan dengan memanfaatkan bahan berlignosesulosa selain kayu, limbah dan kayu berdiameter kecil (Hiziroglu, 2007). Selama ini pemanfaatan kayu berdiameter kecil oleh industri belum optimal padahal jumlahnya cukup besar yaitu dapat mencapai $20 \%$ dari volume kayu yang diproduksi. Jika pada tahun 2005 produksi Hutan Tamanan Industri (HTI) untuk kayu serat sebesar 7,6 juta $\mathrm{m}^{3}$ maka limbah kayu berdiameter kurang dari $10 \mathrm{~cm}$ mencapai 1,5 juta $\mathrm{m}^{3}$ (Anonim, 2007).

Secara teknis limbah tersebut dapat dijadikan sebagai bahan baku serpih untuk pembuatan panel kayu seperti papan serat dan papan partikel. Papan isolasi merupakan bagian dari papan serat dengan kerapatan kurang dari $0,35 \mathrm{~g} / \mathrm{cm}^{3}$ yang dibuat dengan proses basah (Suchsland et al., 1986 dan Anonim, 2003). Papan ini antara lain digunakan untuk penyekat panas (isolator), peredam suara, dan pelapis lantai bagian bawah (Youngquist, 1987).

Di samping panel kayu, terdapat produk lain hasil pengolahan kayu atau bahan berlignoselulosa yaitu arang. Manfaat arang sudah cukup dikenal diantaranya sebagai sumber energi, penjernih dan penghilang bau pada air dan udara. Penggunaan arang pada pembuatan papan isolasi diharapkan dapat berperan menjaga stabilitas dimensi dan meningkatkan kemampuan daya serapnya terhadap bahan polutan. Berdasarkan hal tersebut telah dilakukan penelitian dengan tujuan memanfaatkan kayu berdiameter kecil sebagai bahan baku pembuatan papan isolasi dimana bahan baku tersebut dicampur dengan arang pada komposisi pencampuran tertentu.

\section{BAHAN DAN METODE}

\section{A. Bahan dan Alat}

Bahan baku yang digunakan dalam penelitian ini adalah limbah pembalakan berupa dolog kayu mangium (Acacia mangium Wild) berdiameter kecil $(<10 \mathrm{~cm})$ dari Sumatera Selatan. Perekat yang digunakan adalah tapioka, sedangkan bahan kimia lainnya yang diperlukan adalah $\mathrm{NaOH}$, benzena, kloroform, formaldehida. Arang dibuat dari campuran kayu mangium dan karet (Hevea brasiliensis Muell. Arg.) dengan perbandingan 3:1 (b/b).

Peralatan yang digunakan diantaranya golok untuk membuat serpih, ember stainless steel dan bunsen untuk pemasakan serpih, holander beater dan stone refiner untuk menguraikan serat, decle box untuk membentuk papan, hot press untuk mencetak papan dan universal testing method (UTM) merek Instron untuk menguji sifat mekanis papan isolasi serta peralatan lainnya seperti desikator, oven, kaliper, mikrometer, dan timbangan. 


\section{B. Metode}

Kayu mangium dibuat serpih dengan ukuran $25 \mathrm{~mm}$ × $25 \mathrm{~mm}$ × $3 \mathrm{~mm}$ kemudian dikering udarakan selama satu minggu hingga diperoleh kadar air kesetimbangan. Pemasakan serpih dilakukan dengan proses soda panas terbuka selama 3 jam pada suhu $100^{\circ} \mathrm{C}$ dengan perbandingan serpih dan larutan pemasak sebesar 1:8. Konsentrasi soda $(\mathrm{NaOH})$ teknis yang digunakan sebesar $8 \%$ terhadap berat serpih (b/b). Serpih hasil pemasakan dicuci hingga bersih dari bahan kimia kemudian digiling menggunakan hollander beater (konsistensi $3 \%$ ) dan stoner refiner hingga diperoleh derajat kehalusan serat sekitar $700 \mathrm{ml} \mathrm{CSF}$. Rendemen serat dihitung dengan rumus :

$$
\text { Rendemen }=\frac{\text { berat kering oven serat }}{\text { berat kering oven serpih }} \times 100 \%
$$

Arang serat dibuat dengan cara mengarangkan serat kayu mangium dan karet pada perbandingan $3: 1(\mathrm{~b} / \mathrm{b})$ pada suhu $550^{\circ} \mathrm{C}$. Bahan baku serat dan arang dicampur dengan variasi proporsi (100:0, 90:10, 80:20 dan 70:30) masing-masing secara terpisah di dalam wadah dalam keadaan basah sebelum dimasukkan ke dalam deckle box. Pembentukan lembaran papan isolasi dilakukan dengan proses basah menggunakan deckle box dan alat kempa panas dengan sasaran ukuran $30 \mathrm{~cm} \times 30 \mathrm{~cm}$ × $1 \mathrm{~cm}$ dan kerapatan $0,25 \mathrm{~g} / \mathrm{cm}^{3}$, perekat tapioka yang digunakan sebesar $2 \%$. Pengempaan panas dilakukan pada suhu $120^{\circ} \mathrm{C}$ selama 3 jam. Setelah itu papan isolasi yang terbentuk dikondisikan selama 2 minggu kemudian diuji sifat fisik (kerapatan, kadar air, pengembangan tebal dan daya serap air), sifat mekanis (MOR dan MOE) berdasarkan Standar Jepang (Anonim, 2003) dan daya serap terhadap gas (benzena, kloroform dan formaldehida) yang dilakukan dalam desikator. Metode yang digunakan di dalam pengukuran daya serap papan terhadap gas dilalukan dengan mendekati metode pengukuran daya serap arang aktif (Anonim, 1995). Untuk pengujian daya serap gas, sampel papan isolasi yang digunakan berukuran $5 \mathrm{~cm} \times 5 \mathrm{~cm} \times 1 \mathrm{~cm}$. Sampel tersebut dimasukkan ke dalam desikator yang telah jenuh oleh masing-masing bahan pengujian daya serap tersebut dan dikondisikan selama 24 jam. Pengukuran daya serap dihitung dengan rumus:

$$
\text { Daya serap }=\frac{\text { penambahan berat contoh }}{\text { berat awal }} \times 100 \%
$$

\section{Rancangan Penelitian dan Analisis Data}

Penelaahan data sifat fisik, mekanis, dan daya serap papan isolasi menggunakan analisa keragaman berpola rancangan acak lengkap satu faktor. Faktor tersebut adalah komposisi campuran pulp mangium dan arang dalam 4 taraf yaitu 100:0, 90:10, 80:20 dan 70:30. Selanjutnya jika pengaruh komposisi nyata terhadap sifat fisik, mekanis, dan daya serap, maka penelaahan dilanjutkan dengan uji beda Duncan (Matjik dan Sumertajaya, 2002). 


\section{HASIL DAN PEMBAHASAN}

\section{A. Rendemen dan Sifat Pegolahan Pulp}

Pemasakan serpih kayu mangium dengan proses soda panas terbuka yang dilanjutkan dengan penguraian serat menggunakan hollander beater dan stone refiner menghasilkan rendemen pulp sebesar 78,12\% dengan derajat kehalusan pulp $720 \mathrm{ml} \mathrm{CSF}$. Perolehan rendemen tersebut merupakan rendemen yang umum dihasilkan dari pengolahan pulp semi kimia (60$80 \%$ ), begitu juga dengan derajat kehalusannya juga berada pada selang derajat kehalusan untuk pembuatan papan serat termasuk papan isolasi (Casey, 1980).

\section{B. Sifat Fisik Papan Isolasi}

Penampilan permukaan papan isolasi dengan penambahan arang disajikan pada Gambar 1, dimana semakin besar porsi arang yang ditambahkan, permukaannya semakin gelap. Selanjutnya analisa keragaman menunjukkan bahwa komposisi campuran pulp dan arang berpengaruh nyata terhadap kerapatan, dan sangat nyata untuk kadar air, pengembangan tebal dan penyerapan air papan isolasi (Tabel 1).

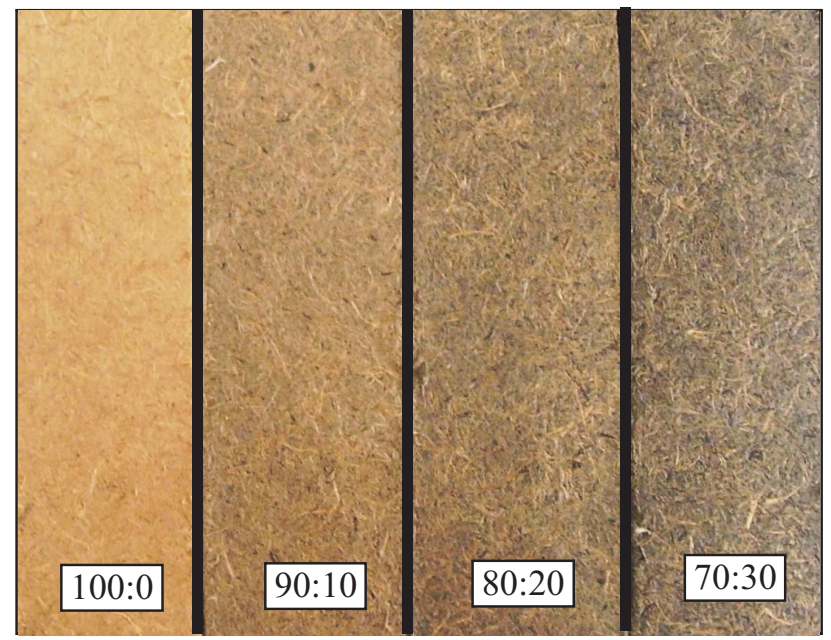

Gambar1. Profil permukaan papan isolasi pada berbagai komposisi campuran pulp mangim dan arang

Figure 1. Surface profile of insulation board at various mixture composition of mangium pulp and charcoal 


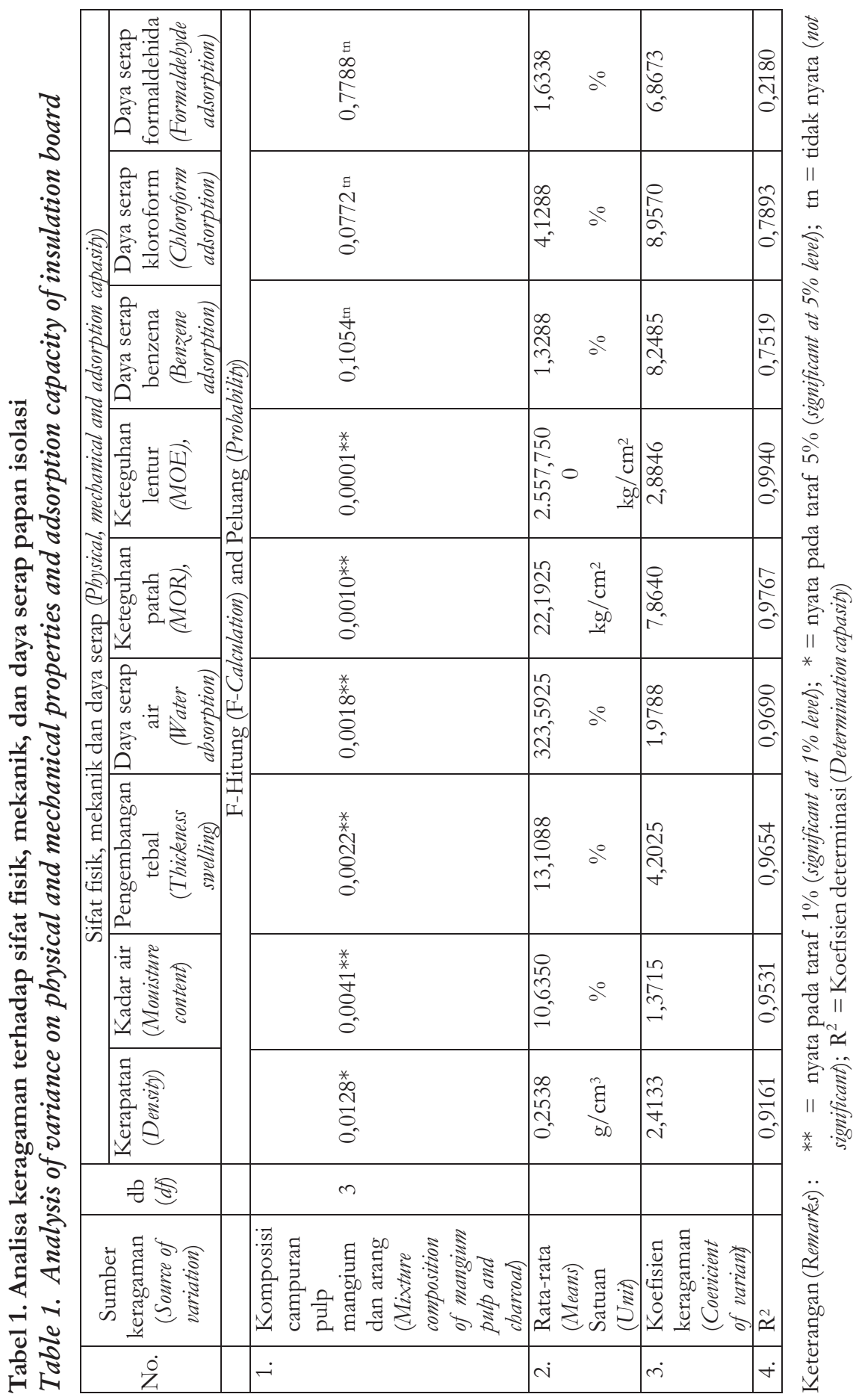


Kerapatan papan isolasi yang dihasilkan berkisar antara $0,23-0,28 \mathrm{~g} / \mathrm{cm}^{3}$ (Tabel 1), seluruh kerapatan tersebut telah memenuhi standar Jepang (Anonim, 2003) yaitu dibawah $0,35 \mathrm{~g} / \mathrm{cm}^{3}$. Berdasarkan hasil uji beda Duncan (Tabel 2), kerapatan pada kontrol $(0,28$ $\mathrm{g} / \mathrm{cm}^{3}$ ) berbeda dengan papan isolasi lainnya. Kerapatan pada komposisi arang 20\% telah sesuai dengan target sasaran dan tidak berbeda dengan kerapatan pada komposisi arang 10\% dan 30\%. Peningkatan komposisi arang cenderung menurunkan kerapatannya. Fenomena ini terjadi karena perubahan ketebalan (springback) papan isolasi yang diperoleh lebih besar pada porsi arang yang tinggi. Hal ini terjadi karena jalinan ikatan saat pembentukan papan isolasi lebih lemah sehingga menghasilkan volume lebih besar (Gambar 2).

Tabel 2. Sifat papan isolasi pada beberapa komposisi campuran pulp mangium dan arang

Table 2. Properties of insulation board at various mixture composition of mangium pulp and charcoal

\begin{tabular}{|c|c|c|c|c|c|c|}
\hline \multirow[t]{2}{*}{ No. } & \multirow{2}{*}{\multicolumn{2}{|c|}{$\begin{array}{c}\text { Sifat papan isolasi, } \\
\text { Properties of insulationboard }\end{array}$}} & \multicolumn{4}{|c|}{$\begin{array}{l}\text { Komposisi pulp dan arang } \\
\text { (Pulp and charcoal composition) }\end{array}$} \\
\hline & & & $100: 0^{*}$ & $90: 10$ & $80: 20$ & $70: 30$ \\
\hline \multirow[t]{2}{*}{1} & \multirow{2}{*}{$\begin{array}{l}\text { Kerapatan } \\
\text { (Density), } \mathrm{g} / \mathrm{cm}^{3}\end{array}$} & Rata-rata, Average & 0,28 & 0,26 & 0,25 & 0,23 \\
\hline & & Kelas, Class & $\mathrm{A}^{* *}$ & B & $\mathrm{BC}$ & $\mathrm{C}$ \\
\hline \multirow[t]{3}{*}{2} & \multirow{3}{*}{$\begin{array}{l}\text { Kadar air } \\
\text { (Moisture content), } \\
\%\end{array}$} & Rata-rata, Average & $11,23^{* * *}$ & 10,87 & 10,46 & 9,99 \\
\hline & & Kelas, Class & $\mathrm{C}$ & $\mathrm{C}$ & $\mathrm{B}$ & $\mathrm{A}$ \\
\hline & & Skor, Score & 1 & 1 & 2 & 3 \\
\hline \multirow[t]{3}{*}{3} & \multirow{3}{*}{$\begin{array}{l}\text { Pengembangan tebal } \\
\text { (Thickness swelling), } \\
\%\end{array}$} & Rata-rata, Average & 16,13 & 13,53 & 12,29 & 10,47 \\
\hline & & Kelas, Class & $\mathrm{C}$ & B & B & $\mathrm{A}$ \\
\hline & & Skor, Score & 1 & 2 & 2 & 3 \\
\hline \multirow[t]{3}{*}{4} & \multirow{3}{*}{$\begin{array}{l}\text { Daya serap air } \\
\text { (Water absorption), } \\
\%\end{array}$} & Rata-rata, Average & 289,24 & 310,39 & 340,98 & 353,76 \\
\hline & & Kelas, Class & $\mathrm{A}$ & A & $\mathrm{B}$ & $\mathrm{B}$ \\
\hline & & Skor, Score & 2 & 2 & 1 & 1 \\
\hline \multirow[t]{3}{*}{5} & \multirow{3}{*}{$\begin{array}{l}\text { Keteguhan patah } \\
\text { (MOR), } \\
\mathrm{kg} / \mathrm{cm}^{2}\end{array}$} & Rata-rata, Average & 35,40 & 21,29 & 17,42 & 14,64 \\
\hline & & Kelas, Class & A & B & $\mathrm{BC}$ & $\mathrm{C}$ \\
\hline & & Skor, Score & 3 & 2 & 1,5 & 1 \\
\hline \multirow[t]{3}{*}{6} & \multirow{3}{*}{$\begin{array}{l}\text { Keteguhan lentur } \\
(M O E), \\
\mathrm{kg} / \mathrm{cm}^{2}\end{array}$} & Rata-rata, Average & 3.648 & 2.508 & 2.220 & 1.854 \\
\hline & & Kelas, Class & $\mathrm{A}$ & $\mathrm{B}$ & $\mathrm{C}$ & $\mathrm{D}$ \\
\hline & & Skor, Score & 4 & 3 & 2 & 1 \\
\hline \multirow[t]{3}{*}{7} & \multirow{3}{*}{$\begin{array}{l}\text { Daya serap benzena } \\
\text { (Benzene adsorption), } \\
\%\end{array}$} & Rata-rata, Average & 1,15 & 1,26 & 1,42 & 1,49 \\
\hline & & Kelas, Class & B & $\mathrm{AB}$ & $\mathrm{AB}$ & $\mathrm{A}$ \\
\hline & & Skor, Score & 1 & 1,5 & 1,5 & 2 \\
\hline \multirow[t]{3}{*}{8} & \multirow{3}{*}{$\begin{array}{l}\text { Daya serap kloroform } \\
\text { (Chloroform adsorption), } \\
\%\end{array}$} & Rata-rata, Average & 3,44 & 3,96 & 4,28 & 4,84 \\
\hline & & Kelas, Class & $\mathrm{B}$ & $\mathrm{AB}$ & $\mathrm{AB}$ & $\mathrm{A}$ \\
\hline & & Skor, Score & 1 & 1,5 & 1,5 & 2 \\
\hline \multirow[t]{4}{*}{9} & \multirow{3}{*}{$\begin{array}{l}\text { Daya serap formal- } \\
\text { dehida (Formaldehyde } \\
\text { adsorption), } \%\end{array}$} & Rata-rata, Average & 1,57 & 1,64 & 1,67 & 1,67 \\
\hline & & Kelas, Class & A & A & A & A \\
\hline & & Skor, Score & 1 & 1 & 1 & 1 \\
\hline & \multicolumn{2}{|c|}{ Jumlah (Total) } & 14 & 14 & 12,5 & 14 \\
\hline
\end{tabular}


Keterangan (Remarks): $*=$ Hasil papan isolasi merupakan pembanding (the resulting insulation board is regarded as control)

** $=$ Berdasarkan hasil uji beda jarak Duncan (based on results of Duncan's multiple range tests)

*** $=$ Penentian skor merupakan manupulasi hasil uji Duncan (score determination as manipulated from Duncan's test's results)

Kadar air papan isolasi berkisar antara 9,99 - 11,23\%, terendah dihasilkan pada papan isolasi dengan komposisi arang sebanyak 30\% dan tertinggi pada komposisi arang 0\%. Berdasarkan uji beda Duncan, kadar air papan isolasi pada komposisi arang 20\% dan 30\% berbeda dengan kadar papan isolasi lainnya. Papan dengan komposisi arang yang kecil cenderung memiliki kadar air lebih besar. Pada saat papan dikondisikan, air yang masih terkandung didalamnya masih terjerap didalam serat karena kayu (serat) bersifat higroskopis, dengan berkurangnya komposisi serat maka kandungan air papan isolasi juga berkurang. Jika dibandingkan dengan standar Jepang (Anonim, 2003) maka papan isolasi yang dibuat memenuhi standar kadar airnya dibawah $13 \%$.

Ketebalan/Thickness (mm)

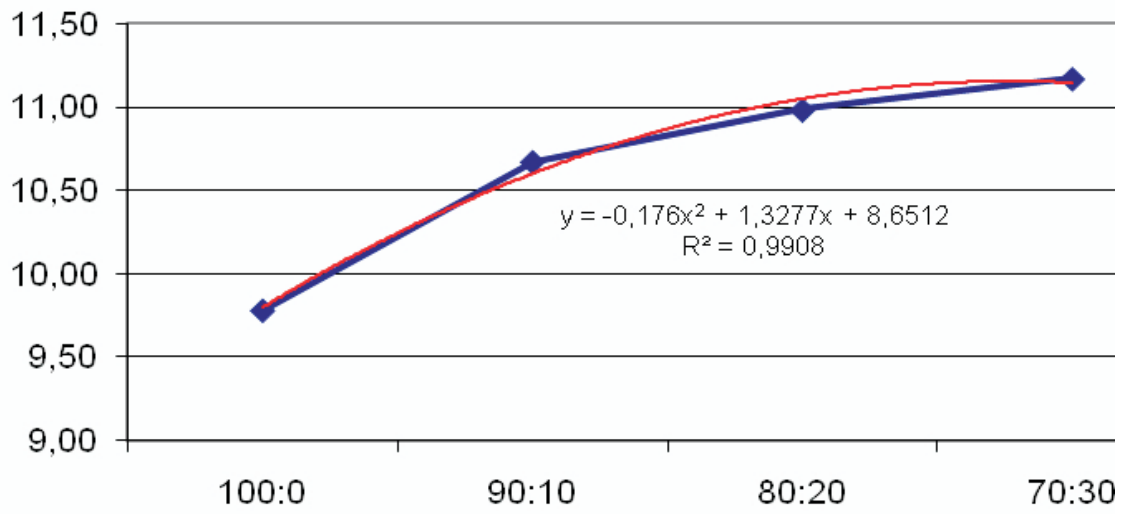

Komposisi campuran pulp mangium dan arang (Mixture composition of mangium pulp and charcoal)

Gambar 2. Ketebalan papan isolasi pada beberapa komposisi campuran pulp mangium dan arang

Figure 2. Thickness of insulation board at various mixture composition of mangium pulp and charcoal 
Pengembangan tebal dan daya serap air papan isolasi berkisar antara 10,47 - 16,13\% dan 289,24 - 353,76\%. Pada papan kontrol diperoleh pengembangan tebal terbesar dan dari hasil uji Duncan (Tabel 2) hasilnya berbeda dengan papan isolasi lainnya, sementara itu daya serapnya terhadap air paling rendah (289,24\%). Daya serap air papan isolasi kontrol relatif sama dengan papan dengan komposisi arang 10\% dan berbeda dengan papan dengan komposisi arang 20\% dan 30\%. Selanjutnya, kecenderungan antara pengembangan tebal dan daya serap papan isolasi berlawanan, dimana semakin besar komposisi arang pengembangan tebalnya semakin kecil sedangkan daya serapnya meningkat. Pengembangan tebal pada papan merupakan interpretasi dari pengembangan selulosa. Selulosa banyak mengandung gugus hidroksil (bersifat polar) yang dapat bereaksi dengan air sehingga terjadi pembengkakkan struktur dan berakibat pada pengembangan papan seperti di ilustrasikan pada Gambar 3 (Fengel and Wegener, 1995). Papan isolasi dengan komposisi serat kayu (selulosa) banyak maka akan mengalami pengembangan tebal yang lebih besar karena pengembangan arang akan lebih kecil dibandingkan dengan pengembangan serat kayunya. Ini disebabkan sifat polaritas arang, mengalami perubahan dibandingkan dengan asal kayunya karena mengalami proses pengarangan (Kim and Lee, 2003; Park et al. 2006).

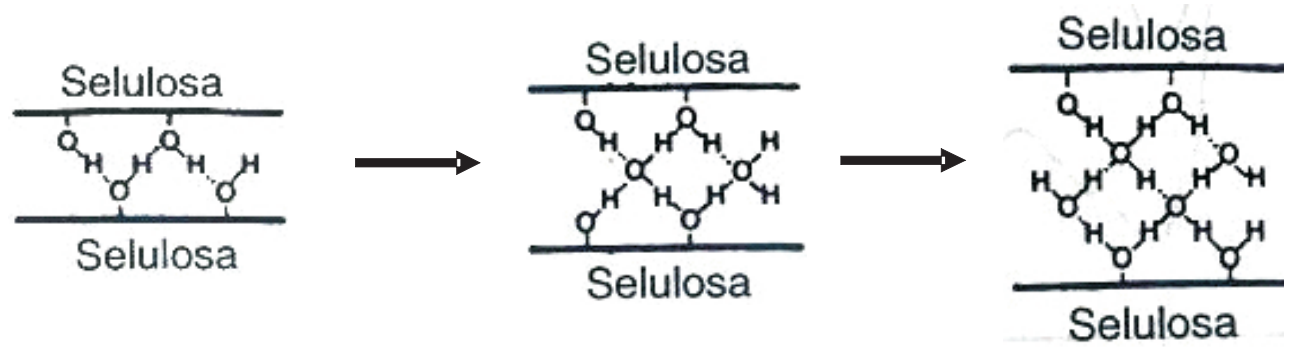

\section{Gambar 3. Pengembangan selulosa oleh air Figure 3. Cellulose swelling on imparted by water}

Fenomena tersebut berlawanan dengan daya serapnya, daya serap terbesar justru terjadi pada papan dengan komposisi arang yang tinggi. Hal ini mengindikasikan bahwa arang berperan besar dalam menyerap air, dimana fenomena ini diduga kuat tidak diakibatkan oleh polaritas arang tetapi lebih disebabkan gaya tegangan permukaan (surface tension) arang tersebut. Di samping itu struktur arang dalam bentuk kristal heksagonal yang porous dan luas permukaannya yang lebih besar sehingga mampu menyerap air kedalam pori-pori arang tetapi karena strukturnya berupa kristal maka pengembangan tebalnya menjadi relatif kecil (Gambar 4). Namun demikian pengembangan tebal pada penelitian ini masih termasuk tinggi sehingga belum memenuhi standar Jepang (Anonim, 2003). Untuk mengatasi masalah terebut maka yang dapat dilakukan adalah dengan meningkatkan suhu kempa atau memperpanjang lama pengempaan sehingga diharapkan akan terjadi proses histeresis pada serat kayu (Tsoumis, 1991). 

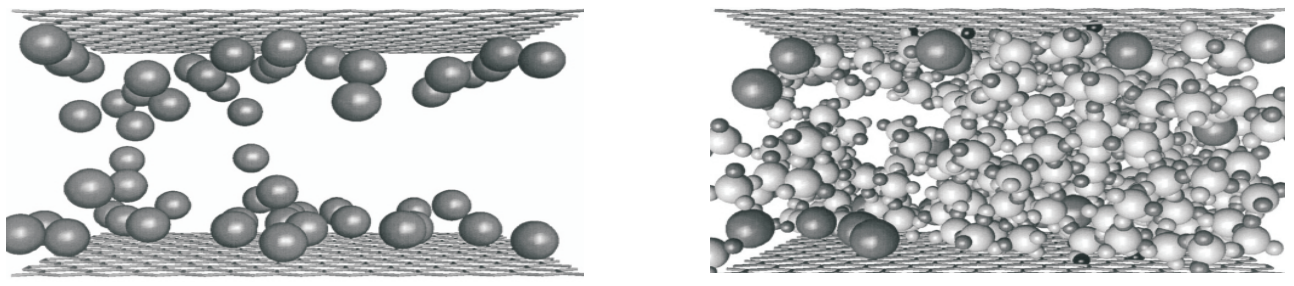

\section{Gambar 4. Kemampuan permukaan arang dalam menyerap air (a) sebelum dan (b) sesudah penyerapan tersebut (Muller, 1998)}

Figure 4. Ability of charcoal surface to adsorp water (a) before (b) after water absorption (Muller, 1998)

\section{Sifat Mekanis Papan Isolasi}

Analisa keragaman menunjukkan komposisi campuran berpengaruh nyata terhadap keteguhan patah dan lentur (Tabel 1). Keteguhan patah (MOR) dan lentur (MOE) papan serat berkisar antara 14,64 - 35,40 kg/ $\mathrm{cm}^{2}$ dan $1.854-3.648 \mathrm{~kg} / \mathrm{cm}^{2}$. Sifat mekanis papan isolasi kontrol lebih baik dibandingkan papan serat dengan penambahan arang (Tabel 2), di mana semakin tinggi komposisi arang kekuatan mekanisnya terus menurun. Berdasarkan hasil uji Duncan, MOR kontrol berbeda dengan papan isolasi perlakuan lainnya, sedangkan pada papan dengan komposisi serat 10\% relatif sama dengan papan pada komposisi $20 \%$ dan berbeda dengan yang 30\%. Sementara itu untuk MOE pada setiap komposisi bahan baku yang berbeda memberikan pengaruh yang berbeda nyata. Pada standar Jepang (Anonim, 2003) untuk kerapatan lebih kecil dari 0,$27 ; 0,35$ dan $0,4 \mathrm{~g} / \mathrm{cm}^{3}$ masing-masing nilai MOR adalah sebesar 10,197; 20,394 dan 30,591 g/ $\mathrm{cm}^{3}$. Dengan demikian MOR papan isolasi yang diperoleh telah memenuhi standar bahkan untuk papan isolasi kontrol MOR nya lebih baik dari standar JIS untuk sheating board (kerapatan $\leq 0,4 \mathrm{~g} / \mathrm{cm}^{3}$ ).

Papan isolasi dengan komposisi arang yang semakin meningkat ternyata cenderung menurunkan sifat mekanisnya. Adanya arang tersebut akan mengganggu daya rekat papan (Kim and Lee, 2003; dan Park et al., 2006). Ikatan serat didalam pembuatan papan isolasi sangat ditentukan oleh ikatan hidrogen yang terjadi diantara permukaan selulosa sehingga terjadi fibrilisasi (Suchland, 1986 dan Fengel 1995). Kehadiran arang (yang telah mengalami perubahan sifat polaritas dibandingkan sifat asal kayunya) diantara serat kayu ternyata dapat menghalangi intensitas persentuhan diantara permukaannya yang akan mengurangi terjadinya ikatan hidrogen. Arang hasil karbonisasi telah merubah struktur selulosa kayu menjadi struktur kristalit heksagonal. Pada struktur tersebut mulai terbentuk senyawa aromatik yang ditandai dengan berkurangnya gugus $\mathrm{OH}$. Pada selulosa gugus $\mathrm{OH}$ tersebutlah yang berperan menjalin ikatan hidrogen diantara selulosa baik secara intramolekul maupun intermolekul (Fengel, 1995; dan Serano et al., 1999).

\section{Daya Serap Papan Isolasi terhadap Bahan Organik}

Daya serap papan serat terhadap benzena berkisar antara 1,15-1,49\% Tabel 1 dan 2). Molekul benzena merupakan cincin aromatik yang mengandung atom karbon dan hidrogen 
berukuran kecil dan mudah menguap pada suhu ruangan. Berdasarkan sifatnya tersebut maka benzena digunakan untuk menguji kemampuan suatu bahan dalam menyerap gas yang bersifat non polar (Hendra dan Darmawan, 2007). Rendahnya daya serap terhadap benzena $/ \mathrm{C}_{6} \mathrm{H}_{6}$ mengindikasikan bahwa papan isolasi yang dihasilkan lebih bersifat polar. Hal tersebut didukung oleh lebih tingginya daya serap terhadap gas kloroform/ $\mathrm{CH}_{3} \mathrm{Cl}(3,44$ 4,84\%) dan formaldehida/HCOH (1,57 - 1,67\%) yang besifat lebih polar (Pari et al., 2006).

Kemampuan daya serap papan isolasi terhadap gas cenderung meningkat dengan bertambahnya komposisi arang, ini diakibatkan oleh struktur arang yang lebih porous dari pada pulp mangium. Persentase peningkatan daya serap tertinggi dihasilkan terhadap gas kloroform kemudian benzena dan formaldehida. Dibandingkan dengan kontrol peningkatan daya serap kloroform mencapai 28,82\% papan papan isolasi dengan komposisi arang 30\%. Peningkatan tersebut lebih tinggi dibandingkan dengan daya serapnya terhadap benzena dan formaldehida (Gambar 5).

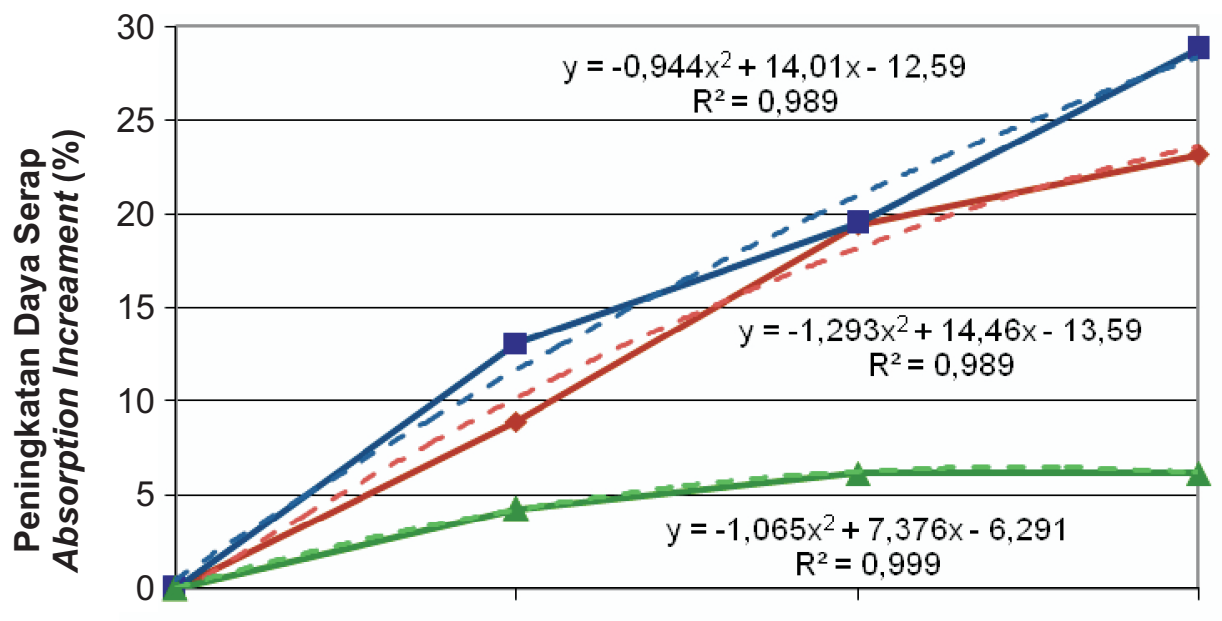
$100: 0$
$90: 10$
- Benzena (Benzene)
- Kloroform (Chloroform)
- Formaldehida (Formaldehyde)
--- Polinomial (Polynomia)

$80: 20$

$70: 30$

Komposisi campuran pulp mangium dan arang (Mixture composition of mangium pulp and charcoal)

Gambar5. Peningkatan daya serap papan isolasi terhadap gas/uap (benzena, khloroform, dan formaldehida) dibandingkan kontrol dengan meningkatnya porsi arang

Figure 5. The increase in adsorption capacity in insulation board toward gas/vapor (benzene, chloroform, and formaldebyde) compared to the control with the increasing portion of charcoal 
Penggunaan arang serat pada pembuatan papan isolasi ternyata mampu meningkatkan daya serapnya terhadap gas yang diuji. Sifat arang yang porous ternyata mampu mengikat gas lebih efektif dibandingkan dengan serat kayunya. Namun demikian peningkatan daya serap tersebut berdasarkan analisa keragaman (Tabel 1) pengaruhnya tidak nyata.

Selanjutnya apabila dilakukan pemeringkatan (scoring) sebagaimana disajikan pada Tabel 2 , terhadap sifat fisik, mekanik dan daya serap, kecuali kerapatan maka papan isolasi pada tiga komposisi bahan baku serat:arang yaitu 100:0, 90:10 dan 70:30 memiliki nilai pemeringkatan yang sama yaitu masing-masing 14 sedangkan pada komposisi 80:20 nilainya lebih kecil yaitu 12,5. Berdasarkan standar JIS, papan isolasi kontrol dengan kerapatan $0,28 \mathrm{~g} / \mathrm{cm}^{3}$ dapat masuk ke dalam kelompok papan isolasi kelas A (Class A Insulation board) dan telah memenuhi syarat untuk kadar air dan MOR sedangkan pengembangan tebalnya belum memenuhi syarat. Untuk papan dengan komposisi 90:10 dan 70:30 dengan kerapatan 0,26 dan 0,23 g/ $\mathrm{cm}^{3}$ masuk kedalam kelompok Tatami board dan telah memenuhi standar JIS untuk kadar air dan MOR-nya tetapi pengembangan tebalnya belum memenuhi standar. Berdasarkan nilai skoring dan sifak fisik-mekanik maka papan isolasi kontrol dan dengan penambahan arang sebesar $10 \%$ adalah yang optimal.

\section{KESIMPULAN DAN SARAN}

\section{A. Kesimpulan}

Secara teknis limbah kayu mangium berdiameter kecil setelah dioleh menjadi pulp dengan proses semikimia dapat digunakan sebagai bahan baku pembuatan papan isolasi dengan rendemen pulp sebesar 78,12\%. Keseluruhan papan isolasi yang dibuat telah memenuhi standar Jepang untuk kerapatan, kadar air dan keteguhan patahnya (MOR), namun pengembangan tebalnya belum memenuhi syarat.

Bertambahnya komposisi arang serat pada pembuatan papan isolasi dapat memperbaiki stabilitas dimensi, kadar air dan daya serapnya terhadap gas terutama kloroform tetapi menurunkan kekuatan mekanisnya (MOE dan MOR). Berdasarkan nilai skoring, kerapatan dan pemenuhan persyaratan Jepang maka papan isolasi yang optimal adalah pada papan kontrol dan papan dengan komposisi pulp:arang 90:10.

\section{B. Saran}

Sifat fisik berupa pengembangan tebal papan isolasi pada penelitian ini belum memenuhi standar Jepang untuk itu perlu dilakukan upaya perbaikan stabilisasi dimensi seperti menaikkan suhu kempa, menambah lama pengempaan atau dengan menggunakan aditif seperti lilin atau minyak pengering (drying seed-oit). 


\section{DAFTAR PUSTAKA}

Anonim. 1995. Standar Nasional Indonesia untuk Arang aktif teknis. SNI 06-3730-1995. Jakarta. Badan Standarisasi Nasional.

Anonim. 2003. Japanese Industrial Standard for Fibreboards No. A 5905. Japanese Standard Association.

Anonim. 2007. Percepatan hutan tanaman industri bisa pakai zonasi. Harian kompas, tanggal 19 April 2007 halaman 18. Jakarta.

Casey, J. P. 1980. Pupl and Paper: Chemistry and chemical technology. Interscience Publisher. New York.

Fengel, D. and G. Wegener. 1995. Kayu: Kimia, Ultrastruktur, Reaksi-reaksi. Terjemahan. Gadjah Mada University Press. Yogyakarta.

Hendra D., dan S. Darmawan. 2007. Sifat arang aktif dari tempurung kemiri. Jurnal Penelitian Hasil Hutan 25(4): 291-302. Pusat Penelitian dan Pengembangan Hasil Hutan. Bogor.

Hirizoglu, S. 2007. Composite panel manufacture from bamboo-rice straw-eucalyptus in Thailand. Makalah disampaikan pada Stadium General Fakultas Kehutanan Institut Pertanian Bogor, 17 Januari 2007. Bogor.

Kim G.E. dan H.H. Lee. 2003. Properties of charcoal-fiber board by wet forming process. International Conference on Forest Products Better Utilization of Wood for Human, Earth and Future Vol.2. Proceeding of The IAWPS.

Matjik, A. A. dan Sumertajaya I. M. 2002. Perancangan Percobaan dengan Aplikasi SAS dan Minitab, Jilid I. IPB Press. Bogor.

Muller, E.A. and K.E. Gubbins. 1998. Molecular simulation study hydrophilic and hydrophobic behavior of activated carbon surfaces. Carbon 36(10): 1433-1438.

Park, S.B., Su-Won K., Jong-Young P., dan Jung-Kwan Roh. 2006. Physical and mechanical properties and formaldehyde emission of particleboard with bamboo charcoal. Journal of Forest Science 69:50-59.

Serrano, V.G., Ferrnando, P.A., Carlos, J.D.V., and Jose P.V. 1999. Formation of oxygen structures by air activation, A Study by FT-IR spectroscopy. Carbon 37: 1517-1528.

Suchsland, O. and D.E. Woodson. 1986. Fiberboard manufacturing practices in the United State. United States Department of Agriculture.

Tsoumis, G. 1991. Science and Technology of Wood : Structure, Properties, Utilization. Van Nostrand Reinhold, New York.

Youngquist. 1987. Wood-based composites and panel product. Wood Hand Book: Wood as an Engineering Material. Forest Product Society, USA. 